\title{
Insulin Binding to Erythrocytes in Children with Type-I Diabetes mellitus
}

\author{
By $R$. Zick, B. Meyer
}

Arbeitsbereich Diabetologie des Zentrums für Innere Medizin und Dermatologie

der Medizinischen Hochschule Hannover,

W. von Schütz

Städtische Kinderklinik Hannover,

W. Holle, A. Dwenger

Abteilung für Klinische Biochemie der Medizinischen Hochschule Hannover,

\section{H. J. Mitzkat}

Arbeitsbereich Diabetologie des Zentrums für Innere Medizin und Dermatologie der Medizinischen Hochschule Hannover and

\section{P. Hürter}

\section{Städtische Kinderklinik Hannover}

(Received May 2/August 26, 1983)

Summary: Specific binding of $\left[{ }^{125} I\right]$ insulin to isolated erythrocytes was investigated in four groups of children

(A) Healthy children under 10 years of age $(n=20)$

(B) Healthy children over 10 years of age $(n=13)$

(C) Diabetic children under 10 years of age $(n=12)$

(D) Diabetic children over 10 years of age $(n=63)$

In addition, all diabetic children $(n=75)$ were subdivided into four groups according to the duration of diabetes

(E) $<2$ years, $(\overline{\mathrm{F}})$ 2-4 years, $(\mathrm{G})$ 4-6 years, and $(\mathrm{H})>6$ years

By means of a nonlinear regression analysis for the extraction of binding parameters (assuming a single receptor class model with independent receptor sites) and methods of variance analysis, statistically significant differences were observed for the receptor affinities $\mathrm{K}_{\mathrm{a}}\left(10^{8} \mathrm{l} / \mathrm{mol}\right)$ and the receptor concentrations $\mathrm{X}_{0}$ ( $n$ mol/l) between groups $A$ and $C, B$ and $D, C$ and $D$, but not between $A$ and $B$. The affinities of groups $C$ and $D$ were found to be higher than the corresponding values of groups $A$ and $B$, whereas the receptor concentrations exhibited an inverse behaviour.

A significant increase of the receptor concentration and decrease of the receptor affinity depending on the duration of diabetes could only be proved to exist during the first 2 years of the disease.

\section{Insulinbindung an Erythrocyten bei Kindern mit Typ-L-Diabetes}

Zusammenfassung: Die Bindung von [ $\left.{ }^{125} \mathrm{I}\right]$ Insulin an Erythrocyten wurde bei vier Gruppen untersucht:

(A) Gesunde Kinder jünger als 10 Jahre $(n=20)$

J. Clin. Chem. Clin. Biochem. / Vol, 21, 1983 / No. 12 
(B) Gesunde Kinder älter als 10 Jahre $(\mathrm{n}=13)$

(C) Diabetische Kinder jünger als 10 Jahre $(\mathrm{n}=12)$

(D) Diabetische Kinder älter als 10 Jahre $(n=63)$

Zusätzlich wurden die diabetischen Kinder $(n=75)$ entsprechend ihrer Diabetesdauer in vier weitere Gruppen unterteilt:

(E) <2 Jahre, (F) 2-4 Jahre, (G) 4-6 Jahre und (H) >6 Jahre

Mit Hilfe einer nichtlinearen Regressionsanalyse zur Ermittlung der Bindungskenngrößen für ein einklassiges Rezeptormodell mit unabhängigen Bindungsstellen und Varianzanalyse wird gezeigt, daß statistisch signifikante Unterschiede zwischen den Rezeptorkonzentrationen $\mathrm{X}_{\mathrm{o}}(\mathrm{nmol} / \mathrm{l})$ sowie den Rezeptoraffinitäten $\mathrm{K}_{\mathrm{a}}$ $\left(10^{8} \mathrm{~V} / \mathrm{mol}\right)$ der Gruppen A und C, B und D, C.und D, jedoch nicht A und B bestehen. Hierbei sind die Rezeptoraffinitäten der Gruppen $C$ und $D$ größer als diejenigen der Gruppen $A$ und $B$, während die Reżèptorkonzentrationen das entgegengesetzte Verhalten zeigen.

Eine signifikante Änderung der Rezeptorkonzentrationen und Rezeptoraffinitäten in Abhängingkeit von der . Diabetesdauer konnte nur innerhalb der ersten 2 Erkrankungsjahre nachgewiesen werden.

\section{Introduction}

Many disorders of glucose homeostasis are characterized by an altered insulin binding to target and non-target cells $(1-3)$.

Children with type-I diabetes, on the other hand, have not been sufficiently studied with respect to their insulin binding (4-6).

This gap is primarily due to the excessive amount of blood required for complete binding studies on circulating leukocytes or monocytes $(4,6,7)$. Recent reports have described insulin receptors on human erythrocytes and have led to the conclusion that erythrocytes can partially be considered as representative of insulin receptors on the cells of other body tissues $(8-10)$.

As complete insulin binding studies on erythrocytes can be carried out with less than $10 \mathrm{ml}$ of whole blood, this method is especially helpful in studies of insulin receptors in children (11).

Though some reports of insulin receptors on erythrocytes in children with type-I diabetes have been published $(4,5,11,12)$, sufficient data with regard to the influence of age and duration of diabetes on the insulin binding on erythrocytes are still lacking.

\section{Materials and Methods}

\section{Subjects}

In 75 ambulatory-treated children $(\delta 28,947)$ aged between 4 and 18 years $(\bar{x} \pm s, 13.28 \pm 3.65$ years) with type-I diabetes the insulin binding to erythrocytes was measured. The duration of diabetes was between one month and fifteen years $(\overline{\mathrm{x}} \pm s, 4.88 \pm$ 2.97 years); the mean age of diabetes manifestation was 8.1 years.
Four groups of children were investigated

(A) Healthy children under 10 years of age $(n=20)$

(B) Healthy children over 10 years of age $(n=13)$

(C) Diabetic children under 10 years of age $(n=12)$

(D) Diabetic children over 10 years of age $(n=63)$

In addition, all diabetic children $(n=75)$ were subdivided into four groups according to the duration of diabetes

(E) $<2$ years, $n=13$

(F) 2-4 years, $n=19$

(G) $4-6$ years, $n=18$ and

(H) $>6$ years $n=25$

All children received an individual mixture of regular and NPH porcine insulin (Nordisk) and the daily insulin requirement was $0.81 \pm 0.27(\bar{x} \pm \mathrm{s}, \mathrm{IU} / \mathrm{kg}$ body weight).

According to the $\mathrm{HbA}_{1 \mathrm{c}}$ values good control was achieved in 28 children and satisfactory control in 29 juvenile diabetics, while control was poor in 18 children.

Control values of the insulin binding to erythrocytes were measured in 33 metabolically healthy children $(\$ 15,18 \delta)$ between 1 and 15 years of age $(8.06 \pm 5.2, \bar{x} \pm s)$.

The body height of all children was between the 25th and 75th percentile; all children had normal weight corresponding to their heights. Liver diseases and renal diseases as well as disturbances of blood formation had been excluded by preliminary examinations.

\section{Insulin binding studies}

12 hours after the last insulin injection and the last food ingestion, approximately $10 \mathrm{ml}$ of heparinized whole blood were taken by venipuncture.

Insulin binding was performed according to the procedure of Gambhir et al. (13) with slight modifications (14). Isolated erythrocytes $\left(3.5-4.5 \times 10^{12} / 1\right)$ were incubated with porcine $\left[{ }^{125} \mathrm{I}\right] \mathrm{in}$ sulin $(0.05 \mathrm{nmol} / /)$ and unlabeled pork insulin $(0.09-1.74 \mathrm{nmol} / /)$ at $15^{\circ} \mathrm{C}$ for 3 hours.

\section{Calculation procedures}

For parameter extraction a nonlinear regression procedure was applied (15). The insulin receptor affinity $\left(\mathrm{K}_{\mathrm{a}}\right)$, the insulin receptor concentration $\left(X_{0}\right)$, and the nonspecific binding $(U)$ were iter- 
atively determined for the one-class binding model via minimization of the sum of the squares of error with the aid of a HP 9835 A computer.

For statistical analyses parametric procedures ( $t$-test for unpaired data) were applied in cases of normal distribution of the data; otherwise nonparametric procedures (Mann-Whitney- and Wilcoxon test, respectively) were employed.

\section{Analytical procedures}

$C$-peptide in serum and daily $C$-peptide excretion in urine were determined radioimmunologically (16). $\mathrm{HbA}_{\mathrm{lc}}$ values in blood were measured according to l.c. (17).

\section{Results}

The juvenile diabetics showed a higher insulin receptor affinity $(p<0.001)$ and a lower insulin receptor concentration $(p<0.001)$ compared with healthy children of the same age.

The most marked differences were observed in the group of children under 10 years of age. With a receptor affinity of 28.9 compared with $8.7 \times 10^{8}$ $\mathrm{I} / \mathrm{mol}$ and a receptor concentration of $0.028 \mathrm{com}$ pared with $0.067 \mathrm{nmol} / /$, the respective values in the diabetic children were $232 \%$ higher and $58 \%$ lower

Tab. 1. Insulin receptor affinity $\left(K_{a} \pm s_{K_{d}}\right)$ and concentration $\left(x_{0} \pm s_{x_{1}}\right)$ in healthy and diabetic children subdivided according to their age.

\begin{tabular}{lcl}
\hline & $\begin{array}{l}\text { Affinity } \mathrm{K}_{\mathrm{a}} \\
\left(10^{8} \mathrm{l} / \mathrm{mol}\right)\end{array}$ & $\begin{array}{l}\text { Concentration } \mathrm{X}_{\mathrm{n}} \\
(\mathrm{nmol} / \mathrm{l})\end{array}$ \\
\hline $\begin{array}{l}\text { Controls }<10 \text { years } \\
\text { (group } \mathrm{A} ; \mathrm{n}=20)\end{array}$ & $8.7 \pm 2.0$ & $0.067 \pm 0.031$ \\
$\begin{array}{l}\text { Controls }>10 \text { years } \\
\text { (group B; } \mathrm{n}=13 \text { ) }\end{array}$ & $8.9 \pm 1.6$ & $0.061 \pm 0.014$ \\
$\begin{array}{l}\text { Diabetic children }<10 \text { years } \\
\text { (group } \mathrm{C} ; \mathrm{n}=12 \text { ) }\end{array}$ & $28.9 \pm 11.7$ & $0.028 \pm 0.016$ \\
$\begin{array}{l}\text { Diabetic children }>10 \text { years } \\
\text { (group D; } \mathrm{n}=63 \text { ) }\end{array}$ & $18.5 \pm 10.4$ & $0.048 \pm 0.028$ \\
\hline
\end{tabular}

than those obtained in the healthy control group. In the diabetics older than 10 years, differences of only $107 \%$ for the insulin receptor affinity (18.5 versus $8.9 \times 10^{8} \mathrm{l} / \mathrm{mol}$ ) and $21 \%$ for the insulin receptor concentration $(0.048$ versus $0.061 \mathrm{nmol} / \mathrm{l})$ were detected (figs. 1, 2; tabs. 1, 2).

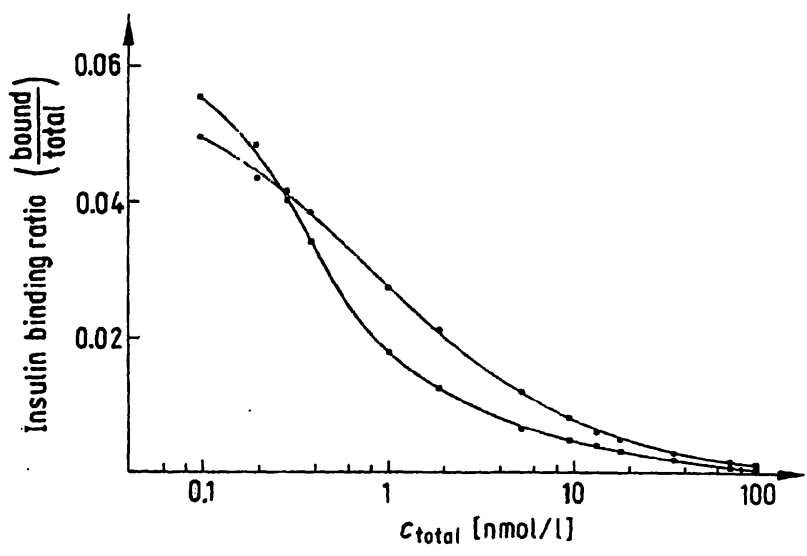

Fig. 1. Specific insulin binding to human erythrocytes $(4 \times$ $\left.10^{12} /\right)$ in healthy $(0)$ and diabetic children $(\mathbb{0})$ younger than ten years.

Means of $\left[{ }^{125} \mathrm{I}\right]$ insulin binding $(\mathrm{B} / \mathrm{T})$ in dependence on the total insulin concentrations $(\mathrm{nmol} / \mathrm{l})$, corrected by iterated unspecific binding.

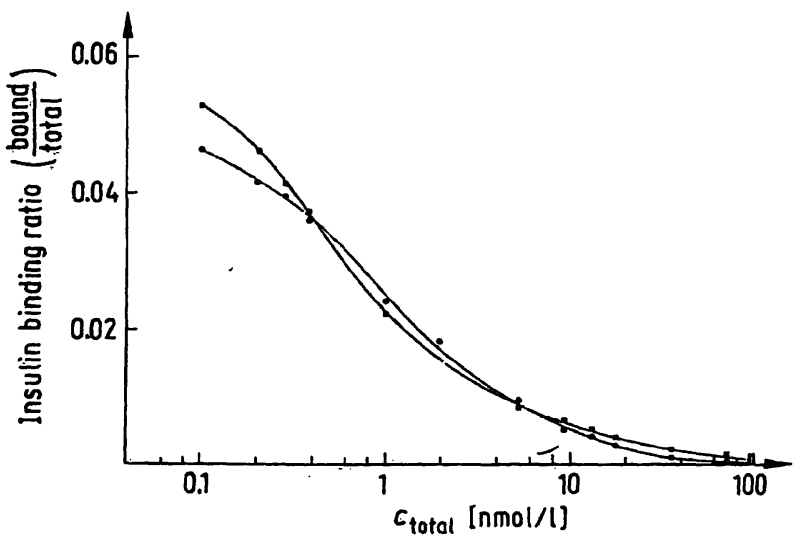

Fig. 2. Specific insulin binding to human erythrocytes $(4 \times$ $\left.10^{12} / 1\right)$ in healthy $(\nabla)$ and diabetic children $(\mathbb{D})$ older than ten years.

Means of $\left[{ }^{125} I\right]$ insulin binding $(B / T)$ in dependence on the total insulin concentrations ( $\mathrm{nmol} / \mathrm{l})$, corrected by iterated unspecific binding.

Tab. 2. Statistical comparison of insulin receptor affinities $\left(K_{a}\right)$ and concentrations $\left(X_{0}\right)$ in healthy and diabetic children subdivided according to their age.

\begin{tabular}{|c|c|c|c|c|}
\hline \multicolumn{2}{|l|}{ Groups } & \multirow{2}{*}{$\begin{array}{l}\text { Diabetic children }>10 \text { years } \\
\text { (group } D ; n=63 \text { ) } \\
p<0.001 \\
p<0.001\end{array}$} & \multirow{2}{*}{$\begin{array}{l}\begin{array}{l}\text { Diabetic children }<10 \text { years } \\
\text { (group } C ; n=12 \text { ) }\end{array} \\
p<0.001 \\
p<0.001\end{array}$} & \multirow{2}{*}{$\begin{array}{l}\text { Controls }>10 \text { years } \\
\text { (group } B: n=13 \text { ) } \\
\text { n.s. } \\
\text { n.s. }\end{array}$} \\
\hline $\begin{array}{l}\text { Controls }<10 \text { years } \\
\text { (group } A ; n=20 \text { ) }\end{array}$ & $\begin{array}{l}\mathbf{K}_{\mathbf{a}} \\
\mathbf{X}_{\mathbf{0}}\end{array}$ & & & \\
\hline $\begin{array}{l}\text { Controls }>10 \text { years } \\
\text { (group } B ; n=13 \text { ) }\end{array}$ & $\begin{array}{l}\mathbf{K}_{\mathrm{u}} \\
\mathbf{X}_{\mathbf{0}}\end{array}$ & $\begin{array}{l}\mathrm{P}<0.001 \\
\mathrm{p}<0.001\end{array}$ & $\begin{array}{l}p<0.001 \\
p<0.001\end{array}$ & \\
\hline $\begin{array}{l}\text { Diabetic children }<10 \text { years } \\
\text { (group } C ; n=12 \text { ) }\end{array}$ & $\begin{array}{l}\mathbf{K}_{\mathbf{a}} \\
\mathbf{X}_{\mathbf{0}}\end{array}$ & $\begin{array}{l}p<0.005 \\
p<0.025\end{array}$ & & \\
\hline
\end{tabular}


An age-dependent change in the insulin receptor affinity and/or the insulin receptor concentration could not be shown in the healthy children (tabs. 1, 2 ). In contrast, the older diabetic children (group $C$ as compared to group D) showed a significantly higher insulin receptor concentration $(0.048$ versus $0.028 \mathrm{nmol} / \mathrm{h} ; \mathrm{p}<0.025$ ) and also a significantly lower insulin receptor affinity (18.5 versus $28.9 \times$ $10^{8} \mathrm{l} / \mathrm{mol} ; \mathrm{p}<0.005$ ) (tabs. 1,2 ).

In addition, the daily insulin requirement was higher in older diabetics $(0.84$ as compared to $0.60 \mathrm{IU} / \mathrm{kg}$ body weight, $\mathrm{p}<0.005)$, the metabolic control was deteriorated $\left(\mathrm{HbA}_{\mathrm{lc}}\right.$ values 0.091 versus $0.073 \mathrm{frac}-$ tion of total haemoglobin, $p<0.01$ ), and - as expected - the duration of diabetes was longer $(p<$ 0.001 ). No statistically significant differences in the residual function of the beta cells (fasting $\mathrm{C}$-peptide value and 24-hour excretion of C-peptide in the urine) could be shown between the two groups of diabetic children (tab. 3).

Within the first 2 years of the disease the receptor affinity fell significantly $(p<0.005$ ) from 30.0 to $19.6 \times 10^{8} \mathrm{l} / \mathrm{mol}$, and the receptor concentration also rose significantly $(\mathrm{p}<0.01$ ) from 0.024 to 0.044 nmol/l (fig. 3; tabs. 4,5 ). In the following years of the disease no further changes could be detected.

Significant changes in the insulin requirement $(p<$ 0.005 ) as well as in the C-peptide excretion in the 24-hour urine ( $p<0.001)$ were also limited to the first 2 years of the disease (tab. 6). The $\mathrm{HbA}_{1 \mathrm{c}}$ values and the fasting $\mathrm{C}$-peptide values, however, were excluded (tab. 6).

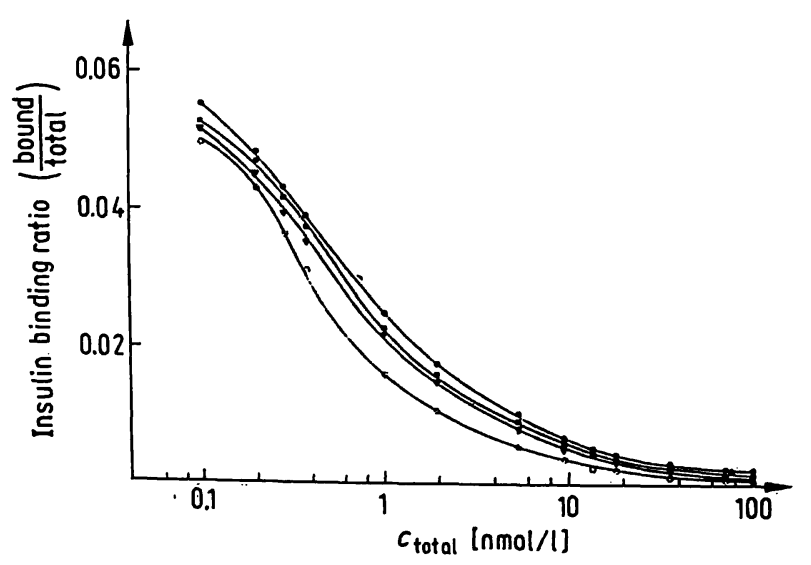

Fig. 3. Specific insulin binding to human erythrocytes $(4 \times$ $\left.10^{12} / 1\right)$ in four groups of diabetic children, subdivided according to the duration of the disease: $(0)<2$ years, $(\Delta)$ 2-4 years, (a) 4-6 years $(\theta)>6$ years.

Means of $\left[{ }^{125} \mathrm{I}\right]$ insulin binding $(\mathrm{B} / \mathrm{T})$ in dependence on the total insulin concentrations (nmol/l), corrected by iterated unspecific binding.
Tab. 3. Duration of diabetes, daily insulin requirement, C-peptide serum levels, daily urinary $C$-peptide excretion and $\mathrm{Hb}_{1 \mathrm{c}}$-values in diabetic children subdivided according to their age $(\bar{x} \pm s)$.

\begin{tabular}{lll}
\hline & $\begin{array}{l}\text { Diabetic } \\
\text { children } \\
<10 \text { years } \\
\text { (group C) }\end{array}$ & $\begin{array}{l}\text { Diabetic children } \\
\text { >10 years } \\
\text { (group D) }\end{array}$ \\
\hline $\mathrm{n}$ & 12 & 63 \\
$\begin{array}{l}\text { Duration of diabetes } \\
\text { (years) }\end{array}$ & $1.85 \pm 1.70$ & $6.38 \pm 3.79^{* * *}$ ) \\
$\begin{array}{l}\text { Daily insulin requirement } \\
\text { (IU/kg body weight) }\end{array}$ & $0.60 \pm 0.30$ & $\left.0.84 \pm 0.24^{* *}\right)$ \\
$\begin{array}{l}\text { C-peptide serum levels } \\
\text { (nmol/l) }\end{array}$ & $0.24 \pm 0.06$ & $0.24 \pm 0.09$ \\
$\begin{array}{l}\text { Daily urinary C-peptide } \\
\text { excretion } \\
\text { (nmol) }\end{array}$ & $2.06 \pm 2.21$ & $1.43 \pm 2.53$ \\
$\begin{array}{l}\text { HbA } \\
\text { (fraction of total }\end{array}$ & $0.073 \pm 0.014$ & $0.091 \pm 0.020^{*}$ ) \\
\begin{tabular}{l} 
haemoglobin) \\
\hline
\end{tabular} & & \\
\hline
\end{tabular}

$\left.\left.\left.{ }^{* * *}\right) \mathrm{p}<0.001 \quad{ }^{* *}\right) \mathrm{p}<0.005 \quad{ }^{*}\right) \mathrm{p}<0.01$

Tab. 4. Insulin receptor affinity $\left(K_{a} \pm s_{K_{2}}\right)$ and concentrations $\left(\mathrm{X}_{0} \pm \mathrm{s}_{\mathrm{n}}\right)$ in four groups of diabetic children subdivided according to the duration of the disease.

\begin{tabular}{lll}
\hline & $\begin{array}{l}\text { Affinity } \mathrm{K}_{\mathrm{a}} \\
\left(10^{8} \mathrm{1} / \mathrm{mol}\right)\end{array}$ & $\begin{array}{l}\text { Concentration } \mathrm{X}_{0} \\
(\mathrm{nmol} / \mathrm{l})\end{array}$ \\
\hline $\begin{array}{l}\text { Duration of diabetes }<2 \text { years } \\
\text { (group } \mathrm{E} ; \mathrm{n}=13 \text { ) }\end{array}$ & $30.0 \pm 8.6$ & $0.024 \pm 0.007$ \\
$\begin{array}{l}\text { Duration of diabetes } 2-4 \text { years } \\
\text { (group } \mathrm{F} ; \mathrm{n}=19)\end{array}$ & $19.6 \pm 9.7$ & $0.044 \pm 0.026$ \\
$\begin{array}{l}\text { Duration of diabetes } 4-6 \text { years } \\
\text { (group } \mathrm{G} ; \mathrm{n}=18)\end{array}$ & $18.3 \pm 9.8$ & $0.044 \pm 0.021$ \\
$\begin{array}{l}\text { Duration of diabetes }>6 \text { years } \\
\text { (group } \mathrm{H} ; \mathrm{n}=25 \text { ) }\end{array}$ & $17.7 \pm 11.5$ & $0.052 \pm 0.031$ \\
\hline
\end{tabular}

\section{Discussion}

The clinical manifestation of type-I diabetes is the consequence of an absolute insulin deficiency preceded by a period of a relative insulin deficiency of varying duration, with an increasing loss of the endogenous insulin secretion (18).

The receptor affinity $K_{\mathrm{a}}$ in the 12 diabetic children with short duration of diabetes (group $\mathrm{E}$ ) exceeded the values obtained in healthy volunteers by an average of $240 \%$, while the receptor concentration $\left(X_{0}\right)$ was $54 \%$ lower than that of healthy volunteers. The more pronounced the differences the shorter was the duration of diabetes. 
Tab. 5. Statistical comparison of insulin receptor affinities $\left(K_{\mathfrak{a}}\right)$ and concentrations $\left(X_{o}\right)$ in four groups of diabetic children subdivided according to the duration of the disease.

\begin{tabular}{|c|c|c|c|c|}
\hline Groups & & $\begin{array}{l}\text { Duration of diabetes } \\
>6 \text { years } \\
\text { (group } H ; n=25 \text { ) }\end{array}$ & $\begin{array}{l}\text { Duration of diabctes } \\
4-6 \text { years } \\
\text { (group } G ; n=18 \text { ) }\end{array}$ & $\begin{array}{l}\text { Duration of diabetcs } \\
2-4 \text { years } \\
\text { (group } F ; n=19 \text { ) }\end{array}$ \\
\hline $\begin{array}{l}\text { Duration of diabetes } \\
<2 \text { years } \\
\text { (group } E ; n=13 \text { ) }\end{array}$ & $\begin{array}{l}K_{\mathbf{a}} \\
\mathbf{X}_{\mathbf{0}}\end{array}$ & $\begin{array}{l}p<0.005 \\
p<0.01\end{array}$ & $\begin{array}{l}p<0.005 \\
p<0.01\end{array}$ & $\begin{array}{l}p<0.005 \\
p<0.01\end{array}$ \\
\hline $\begin{array}{l}\text { Duration of diabetes } \\
2-4 \text { years } \\
\text { (group } F ; n=19 \text { ) }\end{array}$ & $\begin{array}{l}\mathbf{K}_{\mathbf{a}} \\
\mathbf{X}_{\mathbf{n}}\end{array}$ & $\begin{array}{l}\text { n.s. } \\
\text { n.s. }\end{array}$ & $\begin{array}{l}\text { n.s. } \\
\text { n.s. }\end{array}$ & \\
\hline $\begin{array}{l}\text { Duration of diabetes } \\
4-6 \text { ycars } \\
\text { (group } G ; n=18 \text { ) }\end{array}$ & $\begin{array}{l}K_{a} \\
X_{o}\end{array}$ & $\begin{array}{l}\text { n.s. } \\
\text { n.s. }\end{array}$ & & \\
\hline
\end{tabular}

Tab. 6. Daily insulin requirement, C-peptide serum levels, daily urinary $\mathrm{C}$-peptide excretion and $\mathrm{Hb}_{\mathrm{ic}}$-values in four groups of diabetic children subdivided according to the duration of the disease $(\bar{x} \pm s)$.

\begin{tabular}{|c|c|c|c|c|}
\hline \multirow[b]{3}{*}{$\begin{array}{l}\text { Daily insulin requirement } \\
\text { (IU/kg body weight }\end{array}$} & \multicolumn{2}{|c|}{ Duration of diabetes mellitus } & \multirow[b]{2}{*}{$\begin{array}{l}4-6 \text { years } \\
\text { (group } G ; n=18 \text { ) }\end{array}$} & \multirow[b]{2}{*}{$\begin{array}{l}>6 \text { years } \\
(\text { group } \mathrm{H} ; \mathrm{n}=25)\end{array}$} \\
\hline & $\begin{array}{l}<2 \text { years } \\
\text { (group } E: n=13 \text { ) }\end{array}$ & $\begin{array}{l}2-4 \text { years } \\
\text { (group } F ; n=19 \text { ) }\end{array}$ & & \\
\hline & $0.52 \pm 0.34$ & $0.84 \pm 0.26 * *$ & $0.88 \pm 0.21$ & $0.89 \pm 0.19$ \\
\hline $\begin{array}{l}\text { C-peptide serum levels } \\
(\mathrm{nmol} / \mathrm{I})\end{array}$ & $0.33 \pm 0.12$ & $0.21 \pm 0.07$ & $0.23 \pm 0.06$ & $0.22 \pm 0.06$ \\
\hline $\begin{array}{l}\text { Daily urinary C-peptide excretion } \\
\text { (nmol) }\end{array}$ & $4.93 \pm 3.17$ & $1.13 \pm 1.91^{* * *}$ & $1.51 \pm 2.48$ & $0.31 \pm 0.19$ \\
\hline $\begin{array}{l}\text { HbA } A_{1 c} \text {-values } \\
\text { (fraction of total haemoglobin) }\end{array}$ & $0.075 \pm 0.022$ & $0.089 \pm 0.021$ & $0.088 \pm 0.021$ & $0.093 \pm 0.019$ \\
\hline
\end{tabular}

*** $\mathrm{p}<0.001 \quad * * \mathrm{p}<0.005$

The child with the shortest duration of the disease ( $<1$ month) showed an insulin receptor affinity $K_{a}$ $\left(43.5 \cdot 10^{8} \mathrm{~V} / \mathrm{mol}\right)$ of $390 \%$ above that in healthy children and a receptor concentration $\left(\mathrm{X}_{0}\right)(0.015$ $\mathrm{nmol} / 1$ ) of $76 \%$ below that in healthy children.

It seems obvious that, in the preclinical phase of type-I diabetes, the stepwise decrease of the endogenous insulin secretion induces a counterregulatory increase in the insulin receptor affinity and a decrease in the insulin receptor concentration; and this process is reversed by the administration of exogenous insulin.

After onset of the disease a partial remission over a period of months or even years may be observed in many juvenile diabetics, which is characterized by good metabolic control, low insulin requirement $(<0.50 \mathrm{IU} / \mathrm{kg}$ body weight), and a residual insulin secretion $(16,19)$. The partial remission turns into the phase of total diabetes characterized by complete loss of the residual function of the beta cells and an increased insulin requirement $(>0.50 \mathrm{IU} / \mathrm{kg}$ body weight) (16).

J. Clin. Chem. Clin. Biochem. / Vol, 21,.1983 / No. 12
It is only during the phase of partial remission that exogenous insulin and endogenous insulin compete at the receptor site. Depending on the duration of the disease, the portion of endogenous insulin decreases more and more; in the phase of total diabetes the insulin effect at the receptor site is completely exerted by exogenous insulin.

10 of the 13 diabetic children with short duration of diabetes still were in the phase of partial remission. After duration of the disease over a period of more than 4 years (groups $G$ and $H$ ) total diabetes was diagnosed in all children. In group $\mathrm{F}$ (diabetes duration of 2-4 years) only one out of 20 children met the criteria of partial remission.

Since only groups $E$ and $F$ showed changes in the binding parameters depending on the duration of diabetes (i.e., within the first two years of the disease), the change is obviously induced by the successive supplementation of endogenous insulin by exogenous insulin. 
This is proved by the fact that in the phase of total diabetes (groups $\mathrm{F}$ to $\mathrm{H}$ ) no alterations of the binding parameters were observed, and that juvenile diabetics showed an increase in receptor affinity of $106 \%$ and a decrease in the receptor concentration of $57 \%$, in the phase of total diabetes after changing of treatment to biosynthetic human insulin (20). Schlüter et al. (21) even described an increase in the receptor affinity of $200 \%$ in adult type-I diabetics 9 months after changing of treatment to biosynthetic human insulin.

\section{References}

1. Flier, J. S., Kahn, C. \& Roth, H. (1979) N. Engl. J. Med. 300, 413-419.

2. Posner, B. I. (1980) Clin. Invest. Med. 1, 81-85.

3. Beck-Nielsen, H. \& Pedersen, O. (1978) Diabetologia 14, 159-163.

4. Pedersen, O.. Beck-Nielsen, H. \& Heding, L. (1978) Diabetes 27, 1098-1104.

5. Kappy, M. S., Plotnick, L. P., Findlay, J. C. \& Kayne, R. D. (1980) Pediatrics 66, 385-3.90.

6. Fantus, G. I., Ryan, J. \& Gordon, P. (1981) Metabolism 30, 510-517.

7. Pedersen, O. \& Beck-Nielsen, H. (1976) Acta Endocrinol. 83. 556-564.

8. Nerurkar, S. G. \& Gambhir, K. K. (1979) Clin. Chem. 25, $1672-1673$.

9. Robinson. T. J.. Archer. J. A., Gambhir, K. K., Hollis, Jr., V. W., Carter, L. \& Bradley, C. (1979) Science 205, 200-202.

10. Gambhir, K. K., Nerurkar, S. G., Cruz, I. A. \& Hosten, A. O. (1981) Biochem. Med. 25, 62-73.

11. Kappy, M. S. \& Plotnick, L. (1979) Diabetes 28, 10011005.
Finally, the apparent age-dependent differences observed in the binding parameters in diabetic children can be explained as follows. In the group of juvenile diabetics under 10 years of age (group C) 6 out of 12 children were in the phase of partial remission, whereas in the group of older diabetic children (group D) only 5 of 63 met the criteria of partial remission with low insulin requirement and residual insulin secretion.
12. Pedersen, O., Beck-Nielsen, H., Sorensen, N. S. \& Svejgaard, A. (1982) J. Clin. Endocrinol. Metab. 55, 30-39.

13. Gambhir, K. K.,, Archer, J. A. \& Bradley, C. J. (1978) Diabetes 27, 701-708.

14. Dwenger, A., Mitzkat, H. J., Holle, W:, Tost, P. \& Trautschold, I. (1982) J. Clin. Chem. Clin. Biochem. 20, 273-279.

15. Dwengễ, A., Holle, W., Tost, P. \& Trautschold, I. (1983) J. Clin. Chem. Clin. Biochem. 21, 721-729.

16. Zick, R., Hürter, P., Lange, P. \& Mitzkat, H. J. (1982̈) Monatsschr. Kinderheilkd. 130, 209-214.

17. Holloway, C. J., Schlanstedt-Jahn, U., Haeger, I., Mitzkat, H. J. \& Trautschold, I. (1980) In: Electrophoresis (Radola, B. J. ed.) de Gruyter, Berlin, p. 669-678.

18. Cahill, Jr., F. C. \& Mc Devitt, H. O. (1981) N. Engl. J. Med. 304, 1454-1465.

19. Akerbloom, H. K. (1980) Acta Paediatr. Belg. 33, 66.

20. Zick, R., Meyer, B., v. Schütz, W., Holle, W., Dwenger, A., Mitzkat, H. J. \& Hürter, P. (1983) J. Clịn. Çhem. Clin. Biochem. $21,779-78 \overline{2}$.

21. Schlüter, K. J. \& Kerp, L. (1982) Diabẹtes Cạre 5, 152-160.

- Dr. med. Reinhard Zick

Zentrum für Innere: Medizin und Dermatologie Arbeitsbereich Diabetologie Medizinische Hochschule Hannover Konstanty-Gutschow-Str. 8 D-3000 Hannover 61 